\title{
Protecting the Health of First Nation Personnel at Contaminated Sites: A Case Study of Mid-Canada Radar Line Site 050 in Northern Canada
}

\author{
LEONARD J.S. TSUJI, ${ }^{1}$ BRUCE C. WAINMAN,${ }^{2}$ JEAN-PHILIPPE WEBER,${ }^{3}$ CELINE SUTHERLAND,${ }^{4}$ \\ BILLY KATAPATUK $^{5}$ and EVERT NIEBOER ${ }^{6}$
}

(Received 6 February 2004; accepted in revised form 16 December 2004)

\begin{abstract}
Recently, First Nation (FN) organizations have entered into agreements with federal and provincial government representatives to remediate radar-line sites in Ontario. These agreements stipulated that FN people would take part in the site delineation and remediation process to gain job experience and economic benefits. One important aspect of the process was protecting FN personnel from contaminant exposure and thus, from potential negative health outcomes associated with the cleanup work itself. In this paper, we describe the safety precautions used by FN workers preparing Mid-Canada Radar Line (MCRL) Site 050 for Phase 2 of the delineation process and the health monitoring protocol that was tested. We measured concentrations of total polychlorinated biphenyls (PCBs as Aroclor 1260), 14 individual PCB congeners, p, p'-DDT, p,p'-DDE, nine other organochlorine pesticides, and lead in the blood of Fort Albany FN workers before they started work at Site 050 and approximately a week before they completed their three-month work period in the contaminated zone. No significant differences were found in the paired samples. These results indicate that the safety precautions taken were adequate for the work and the site in question. The monitoring protocol discussed here may be used as a template and modified to meet the specific needs of other projects. The results of this study are important because other Aboriginal groups have entered or will be entering into agreements with government organizations for the remediation of other MCRL sites in Ontario and across Canada.
\end{abstract}

Key words: Mid-Canada Radar Line, remediation, First Nations, PCBs, occupational health

RÉSUMÉ. Les stations de ligne radar désaffectées situées tant dans l'Arctique que dans le Subarctique canadiens seraient des sources ponctuelles de contamination. Des organismes des Premières nations ont participé dernièrement, avec des représentants des gouvernements fédéral et provinciaux, à des accords visant l' assainissement des stations de ligne radar en Ontario. Ces accords stipulaient que des membres des Premières nations prendraient part à la délimitation des sites et au processus d'assainissement afin d'acquérir de l'expérience de travail et de profiter des retombées économiques. Un volet important de ce processus visait à protéger le personnel autochtone de l'exposition aux contaminants et donc, d'effets potentiels négatifs pour la santé associés aux opérations de nettoyage mêmes. Dans cet article, on décrit les mesures de sécurité utilisées par les travailleurs autochtones œuvrant sur le site 050 de la ligne radar Mid-Canada durant la phase 2 du processus de délimitation, ainsi que le protocole de contrôle de la santé mis alors à l'essai. On a mesuré les concentrations de l'accumulation de diphényles polychlorés (PCB comme l'Arochlore 1260), de 14 congénères de PCB, de p,p'-DDT, de p,p'-DDE, de neuf autres pesticides organochlorés ainsi que de plomb dans le sang des travailleurs autochtones de Fort Albany avant qu'ils commencent à travailler au site 050 et une semaine environ avant qu'ils terminent leur période de travail de trois mois dans la zone contaminée. On n'a pas trouvé de différences significatives entre les échantillons appariés. Ces résultats révèlent que les mesures de sécurité prises étaient adéquates pour le travail et le site en question. Le protocole de contrôle discuté ici pourrait servir de modèle et être adapté pour répondre aux critères spécifiques d'autres projets. Les résultats de cette étude sont importants car d'autres groupes autochtones participent actuellement ou vont participer à des accords avec des agences gouvernementales visant l'assainissement d'autres sites de la ligne radar Mid-Canada en Ontario et à travers le Canada.

Mots clés: ligne radar Mid-Canada, assainissement, Premières nations, PCB, santé au travail

Traduit pour la revue Arctic par Nésida Loyer.

\footnotetext{
${ }^{1}$ Department of Environment and Resource Studies, University of Waterloo, Waterloo, Ontario N2L 3G1, Canada; ljtsuji@ fes.uwaterloo.ca

${ }^{2}$ McMaster University, Department of Obstetrics and Gynecology, St. Joseph's Hospital, Hamilton, Ontario L8N 4A6, Canada

${ }^{3}$ Institut national de santé publique du Québec, Centre de toxicologie du Québec, Sainte-Foy, Québec G1V 5B3, Canada

${ }^{4}$ Peetabeck Health Services, Fort Albany, Ontario P0L 1H0, Canada

${ }^{5}$ Washaw Sibi Eeyou Cree Nation, Amos, Quebec J9T 1H7, Canada

${ }^{6}$ Department of Biochemistry, McMaster University, Hamilton, Ontario L8N 3Z5, Canada

(C) The Arctic Institute of North America
} 


\section{INTRODUCTION}

During the 1950s, radar stations were built in North America in response to the threat of a nuclear attack from the Russian Arctic region (Huebert, 2000; Myers and Munton, 2000). Three series of manned and unmanned radar-line stations were built: the Pinetree Line, a joint CanadianAmerican effort, at approximately the 49th parallel; the Mid-Canada Radar Line (MCRL) or McGill Fence, a solely Canadian project, at the 55th parallel; and the Distant Early Warning (DEW) Line, a primarily American undertaking, at the 70th parallel (Huebert, 2000; Myers and Munton, 2000). The 98 MCRL sites were in operation until 1965, when they were deemed redundant for both strategic and economic reasons (ESG, 1999a; Thorne, 2003). After closure, the MCRL stations in the Subarctic were not properly decommissioned (Gibson, 1993). Other radar-line sites have been point sources of contaminants (especially PCBs and lead) in the Canadian North (Bright et al., 1995a, b, c; Dushenko et al., 1996; ESG, 1999a; Poland et al., 2001). In 1997, representatives of the Canadian federal government, the Government of Ontario, and the First Nations (FNs) of the western James Bay region (northern Ontario) entered into a partnership to investigate the MCRL sites in Ontario and make recommendations for remediation of these sites if required (ESG, 1999b).

One objective of the MCRL remediation process in Ontario was for "First Nations in the area [to] capture a reasonable share [of] the business and training opportunities associated with the clean-up" (Hunter, 1998:3). Consultation was held with both FN political leaders and communities, and there was a consensus among FNs that they would like to be involved in the delineation and remediation process through employment and training opportunities (ESG, 1999a). Indeed, the Memorandum of Understanding (MOU) between Fort Albany FN (regarding Site 050, the first MCRL site scheduled for remediation) and the Ontario Ministry of Natural Resources (OMNR) stated specifically that all tender responses must address the issue of local FN hiring (OMNR, 2000). Health protection was also mentioned by the Canadian Department of Defence (Downs, 1999) with respect to ensuring that no detrimental health effects would be associated with the cleanup work itself.

Initial delineation of MCRL Site 050 revealed extremely high concentrations of polychlorinated biphenyls (PCBs): up to $21000 \mathrm{ppm}$ in soil and up to $550 \mathrm{ppm}$ in vascular plants. Environmental media containing PCB concentrations higher than $50 \mathrm{ppm}$ are considered hazardous waste (ESG, 1999a). Lead is another major contaminant that has been detected at levels of concern (39700 ppm in paint) at Site 050 . Other relatively minor contaminants that have been identified at MCRL sites in Ontario include the pesticides DDT, dieldrin, chlordane, and heptachlor (ESG, 1999a).

PCBs are mixtures of a possible 209 congeners that differ in their degree of chlorination and stereochemical structure (Skerfving et al., 1994). PCBs are readily absorbed through the gastrointestinal system, and skin and lung absorption are other routes of exposure. Once in the body, PCBs are widely distributed (Skerfving et al., 1994). In a review of human health effects, James et al. (1993) assert that the only adverse health effects attributable to PCB exposure are dermal: inflammation or edema of skin and eyes, thickening of skin and fingernails, and chloracne (pustules, blackheads, or cysts in malar regions of the face, the scalp, and the back of the neck). Although there has been some evidence that PCBs induce hepatic enzymes (e.g., serum g-glutamyl transpeptidase, known as GGT), the significance of this induction has been questioned because any changes in hepatic enzyme levels were still in the normal range (James et al., 1993). Moreover, other factors, such as an alcoholic liver and exposure to several therapeutic drugs and drugs of abuse, can cause an increase in GGT (Kimbrough, 1995). Recently, associations between PCBs in human fluids and negative health outcomes have been reported. These include significant associations between increasing chlorinated hydrocarbons (including PCBs) in blood and immunological and hormonal changes in women (Gerhard et al., 1998); a strong, dose-response relationship between serum PCBs and risk of non-Hodgkin's lymphoma (Rothman et al., 1997); and a negative association between post-natal exposure to PCBs in milk and cognition in children (Walkowiak et al., 2001). However, correlation does not necessarily equate with causality; thus, there is a need to elucidate the mechanism(s) of PCB action before the significance of these studies can be assigned (Gerhard et al., 1998; Hansen, 1998), and numerous researchers dispute the role of PCBs and other organochlorines in cognitive and reproductive health (Safe, 2000; Foster and Holloway, 2003). Nevertheless, PCBs in Canada were voluntarily removed from open systems (in direct contact with the environment) during the early 1970s, and in 1976, federal legislation restricted all uses, including use in closed systems having no external contact with the environment, and also promulgated disposal procedures for PCBs (Frank et al., 1993; AMAP, 1998).

By contrast, the detrimental effects of lead have been well characterized (Levin and Goldberg, 2000). Lead is a toxic metal that can cause detrimental effects to all bodily systems. However, one question is whether there exists a threshold of lead toxicity. Some researchers suggest that there may be no lower limit of medical concern for lead: that is, any uptake of lead is detrimental to human health (Ferber, 2002; Rogan and Ware, 2003).

It follows that safety measures would be required for any person working in contaminated MCRL sites. For this reason, a two-week course on handling hazardous waste was given by an eastern Canadian consulting company to all Fort Albany FN workers who would be preparing Site 050 for Phase 2 of the delineation process. Phase 1, the initial characterization of the site, included cataloguing physical hazards for later disposal, identifying hazardous 
materials (e.g., asbestos), and collecting various samples (e.g., soil, vascular plants, paint) originating from the abandoned MCRL site for analysis. Extensive vegetation at Site 050 made it impossible to fully characterize the extent of PCB contamination in the soil and other receptors on the site (e.g., woody plants and their fruit) during Phase 1. Thus, before further investigation could take place, Fort Albany FN workers would have to clear trees and brush from the clean and contaminated areas of Site 050 (ESG, 1999a; G. Iannucci, Fort Albany FN MCRL Project Coordinator, pers. comm. 2004). These workers would also build a new chain-link fence in the uncontaminated portion of Site 050 to enclose the contaminated area, as well as two new buildings in the clean area: a decontamination building, with change room and shower, and a $24^{\prime} \times 24^{\prime}$ kitchen/lunchroom building for personnel working on the actual remediation of the site (ESG, 1999b; G. Iannucci, pers. comm. 2004). Test holes for monitoring were also to be dug (ESG, 1999b; G. Iannucci, pers. comm. 2004).

Safety measures for FN personnel preparing MCRL Site 050 for Phase 2 of delineation included wearing appropriate respirators (AO Safety, PA-55500 respirator, RC-R53HE-P100 cartridge), goggles, gloves, and disposable, full-body suits (North Safety, CT-5005-2X; these throwaway coveralls were changed daily). Workers showered every day and had a separate "clean" change room. In the clean area, street clothes were worn, and no precautions were taken. In the lunchroom, coveralls were removed; clothing was also removed prior to use of the toilets (G. Iannucci, pers. comm. 2004). Although these safety measures were in place to reduce or eliminate excessive exposure and uptake of contaminants, especially PCBs and lead, a monitoring program was needed to test their efficacy in protecting the workers. Health outcomes sensitive to low-level changes in body burden of PCBs (the main contaminant at Site 050) are generally not well characterized and may be due to confounders. Therefore, a change in a worker's body burden of PCBsmeasured before the start of work on the contaminated site and approximately a week before the end of the threemonth work term-was used as a measure of health protection for the workers. A significant change in body burden of PCBs in a person during this work period would indicate a need to re-examine existing safety measures. For consistency, the same criteria used for PCBs were employed for other contaminants, even though contaminants such as lead have relatively more sensitive and reliable biochemical markers for exposure (e.g., ALAD activity; Lauwerys and Hoet, 2001).

In this study, we measured concentrations of total PCBs (as Aroclor 1260), 14 PCB congeners, p,p'-DDT, p,p'DDE, nine other organochlorine pesticides, and lead in Fort Albany FN workers before they began work in the contaminated zone and approximately a week before they completed it to determine whether the safety precautions taken were sufficient to prevent an increase in contaminant body burden over the three-month work period. This information is important in identifying any need to modify existing precautionary methods before the full cleanup of Site 050 (i.e., the removal of hazardous waste for incineration). The methods described here, if shown to be effective, can be used as a template on which to design a workermonitoring program for other Aboriginal organizations that contemplate partnering in the remediation of abandoned radar-line sites or work in any contaminated sites.

\section{MATERIALS AND METHODS}

\section{Study Site}

Fort Albany FN is located on the west coast of James Bay, Ontario, Canada $\left(52^{\circ} 15^{\prime} \mathrm{N}, 81^{\circ} 35^{\prime} \mathrm{W}\right)$, on the south shore of the Albany River (Hill, 1999; Tsuji et al., 2001). Approximately 850 people live in the community, and Cree is still the predominant spoken language (Tsuji et al., 2001). The village is located on Sinclair Island, but people also inhabit the mainland and Anderson Island (Tsuji et al., 2001; Fig. 1). The abandoned MCRL station (Site 050) in the Fort Albany community is located on Anderson Island (ESG, 1999a; Fig. 1).

\section{Sample Collection}

To monitor the potential change in body burden of contaminants for all FN workers preparing Mid-Canada Radar Line Site 050 for delineation, Phase 2 (June to August 1999; approximately three months of work in the contaminated zone), we collected matched blood samples (before and after exposure on the site) for nine of the workers. Samples were taken before work began on the contaminated site and approximately a week before its completion. Although pre-job blood samples were collected for two additional workers, the end-of-job specimens were not; therefore, these two individuals were not included in the study group. Blood was collected early in the morning, and participants were asked whether they had consumed anything that morning. Participants were told not to eat or drink anything after midnight the day before collection, as non-fasting is known to affect organochlorine levels in humans (Sandanger et al., 2003). However, diabetic workers were allowed to eat something in the morning as long as the food or drink did not contain lipids. Blood samples for organochlorine analyses were collected in lavender-top, $10 \mathrm{ml}$ glass Vacutainer ${ }^{\circledR}$ tubes containing ethylenediaminetetracetic acid (EDTA; Becton-Dickinson \#7665). Blood was gently mixed with the anticoagulant (EDTA) in the Vacutainer tube and then centrifuged at room temperature (at $1000-1200 \mathrm{xg}$ for 10 minutes). The resultant plasma was then transferred from the Vacutainer tube with solvent-washed polyethylene pipettes to shatterresistant, solvent-washed glass vials. The glass vials were then frozen and stored at $-20^{\circ} \mathrm{C}$. Blood samples for lead determination were collected in lavender-top, $6 \mathrm{ml}$ plastic 


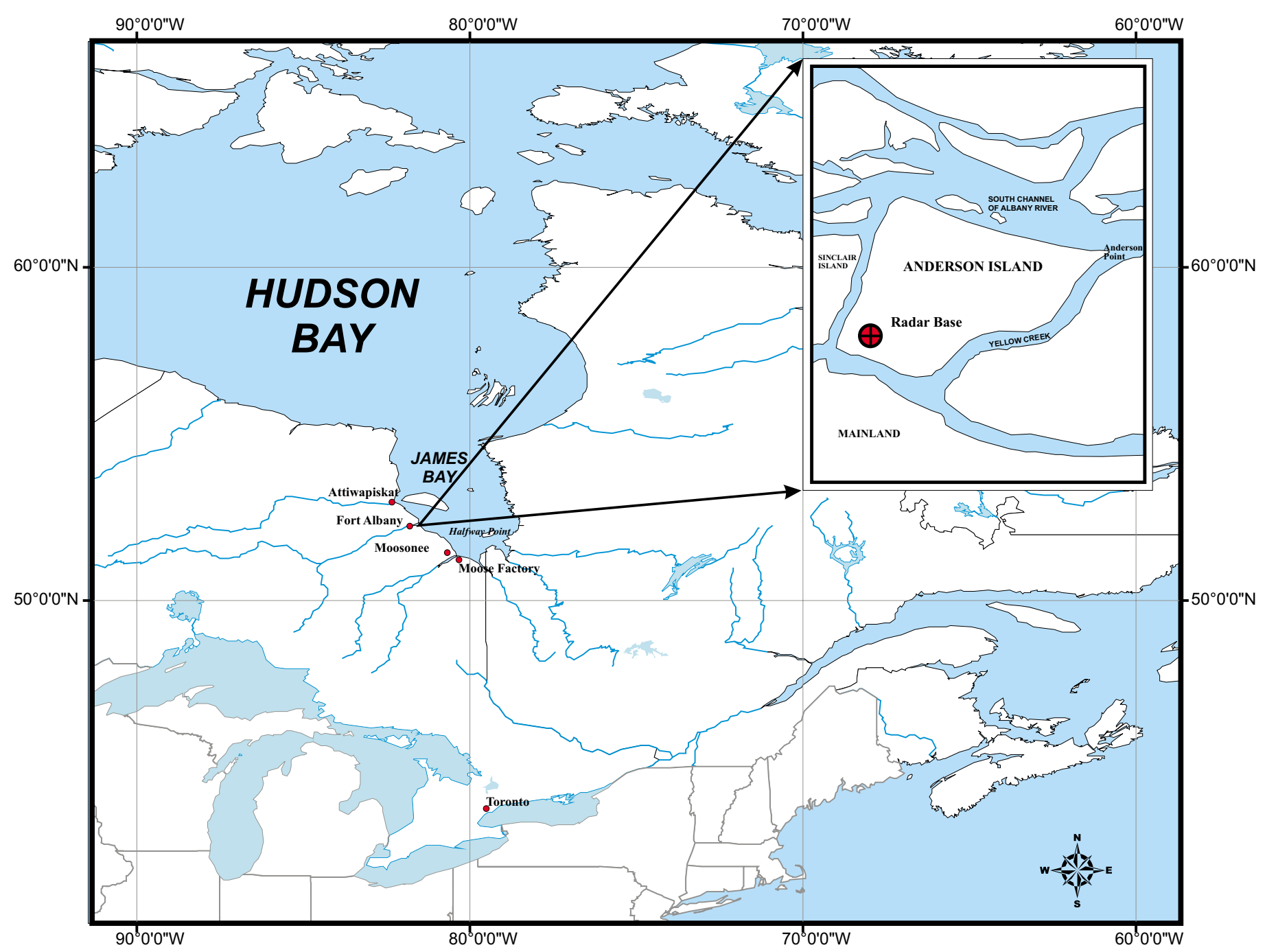

FIG. 1. The location of the contaminated area/Mid-Canada Radar Line Site 050.

Vacutainer tubes containing EDTA (Becton-Dickinson \#7863). The blood samples were gently mixed with the anticoagulant, allowed to cool down at room temperature, then frozen and stored at $-20^{\circ} \mathrm{C}$. All plasma and whole blood samples were shipped frozen, in a Styrofoam cooler over frozen gel packs, to the Centre de toxicologie du Québec, Sainte-Foy, Quebec, for analyses.

\section{Sample Analyses}

Soil contamination at the MCRL sites in Ontario has been shown to be primarily Aroclor 1260, with little Aroclor 1254 (ESG, 1999b). Contaminated paint chips have been shown to contain either Aroclor 1260 or Aroclor 1254 (ESG, 1999a). Plasma concentrations of total PCBs (as Aroclor 1260), 14 individual PCB congeners (28, 52, 99, 101, 105, 118, 128, 138, 153, 156, 170, 180, 183, 187), p,p'-DDT and its major metabolite p,p'-DDE, and nine other organochlorine pesticides (aldrin, $\beta$-BHC, $\alpha$-chlordane, $\gamma$-chlordane, cis-nonachlor, hexachlorobenzene, mirex, oxychlordane, and transnonachlor) were measured. Prior to quantitative determination by gas chromatography, the samples were cleaned up by column chromatography using established methods (AMAP, 1998). Peaks were identified by their relative retention times obtained on dual capillary columns. Detection limits, based on three times the average standard deviation of noise, were $0.02 \mu \mathrm{g} / \mathrm{L}$ for PCB congeners and chlorinated pesticides, $0.04 \mu \mathrm{g} / \mathrm{L}$ for p,p'-DDT and $\beta$-BHC, and $0.2 \mu \mathrm{g} / \mathrm{L}$ for total PCB as Aroclor 1260. Total lipids were determined by routine clinical chemistry methods. The Centre de toxicologie du Québec is accredited under ISO 17025 by the Standards Council of Canada; uses suitable calibration standards, intralaboratory control samples, and reference materials; and co-ordinates an interlaboratory quality control program for metals and organochlorines (Weber, 1996). Percent recoveries of standards were all $95 \%$ or higher. Duplicate samples $(n=2)$ were on average within $5 \%$ of original values except for $\beta$-BHC; these concentrations were at the limit of quantification and within $12 \%$ of the original values.

All lead analyses were determined by electrothermal atomic absorption spectrometry, using state-of-the-art instrumentation (Perkin Elmer model ZL 4100). Samples 
TABLE 1. Concentrations of contaminants $(\mu \mathrm{g} / \mathrm{L})$ in Mid-Canada Radar Line workers prior to $\left(\mathrm{T}_{0}\right)$ and after $\left(\mathrm{T}_{1}\right)$ working in the contaminated site.

\begin{tabular}{|c|c|c|c|c|c|c|c|c|c|c|c|c|}
\hline \multirow[t]{2}{*}{ Worker } & \multicolumn{2}{|c|}{ Aroclor 1260} & \multicolumn{2}{|c|}{$\Sigma \mathrm{DDT}$} & \multicolumn{2}{|c|}{ Hexachlorobenzene } & \multicolumn{2}{|c|}{ Oxychlordane } & \multicolumn{2}{|c|}{ Trans-nonachlor } & \multicolumn{2}{|c|}{ Lead } \\
\hline & $\mathrm{T}_{0}$ & $\mathrm{~T}_{1}$ & $\mathrm{~T}_{0}$ & $\mathrm{~T}_{1}$ & $\mathrm{~T}_{0}$ & $\mathrm{~T}_{1}$ & $\mathrm{~T}_{0}$ & $\mathrm{~T}_{1}$ & $\mathrm{~T}_{0}$ & $\mathrm{~T}_{1}$ & $\mathrm{~T}_{0}$ & $\mathrm{~T}_{1}$ \\
\hline 1 & 5.3 & 6.1 & 3.16 & 3.43 & 0.23 & 0.23 & 0.16 & 0.18 & 0.19 & 0.23 & 93 & 83 \\
\hline 2 & 0.95 & 0.79 & 0.94 & 0.76 & 0.07 & 0.05 & 0.04 & 0.04 & 0.05 & 0.04 & 5 & 29 \\
\hline 3 & 0.42 & 0.29 & 0.49 & 0.50 & 0.06 & 0.05 & 0.03 & 0.02 & 0.03 & 0.02 & 17 & 15 \\
\hline 4 & 2.1 & 2.0 & 1.26 & 1.27 & 0.11 & 0.11 & 0.05 & 0.05 & 0.05 & 0.05 & 15 & 15 \\
\hline 5 & 1.4 & 1.4 & 0.68 & 0.80 & 0.06 & 0.06 & 0.03 & 0.05 & 0.05 & 0.06 & 60 & 44 \\
\hline 6 & 4.0 & 4.1 & 1.88 & 1.78 & 0.14 & 0.16 & 0.07 & 0.07 & 0.10 & 0.10 & 42 & 35 \\
\hline 7 & 1.2 & 1.0 & 0.91 & 0.95 & 0.09 & 0.07 & 0.04 & 0.03 & 0.04 & 0.04 & 48 & 83 \\
\hline 8 & 0.27 & 0.40 & 0.47 & 0.53 & 0.04 & 0.04 & 0.02 & 0.03 & 0.02 & 0.03 & 48 & 37 \\
\hline 9 & 4.0 & 3.8 & 2.73 & 2.64 & 0.13 & 0.15 & 0.17 & 0.17 & 0.21 & 0.21 & 21 & 27 \\
\hline
\end{tabular}

were simply diluted and injected into the instrument. Matrix matched calibration was performed using reference material from the Institut national de santé publique du Québec/Centre de toxicologie du Québec's interlaboratory comparison program. Routine checks for accuracy and precision also used reference material from this program. Periodic evaluations were performed using outside proficiency testing schemes (e.g., U.S. Centers for Disease Control and Prevention; New York State Department of Health). The detection limit for lead was $10 \mu \mathrm{g} / \mathrm{L}$, based on three times the average standard deviation of the noise.

We interviewed all participants, using a pre-established questionnaire, to obtain data on personal identification, medical history, and lifestyle factors, including the level of consumption of traditional foods, as well as on community demographics. These data would be used, along with PCB congener data, if any significant changes in contaminant body burden of the MCRL workers aroused suspicion that contaminant loads were confounded by aspects of lifestyle.

\section{Statistical Analysis}

Organochlorine contaminant data were screened to eliminate from further analyses those samples with no detectable organochlorine concentrations. Statistical analyses were limited to those organochlorines for which all of the samples had levels above the detection limits, namely, total PCBs as Aroclor 1260, $\mathrm{EDDT}$ (p,p'-DDT + p,p'DDE), hexachlorobenzene, oxychlordane, and transnonachlor. Samples with no detectable concentrations were recorded for aldrin (100\%; i.e., $100 \%$ of the samples did not have concentrations above the detection limit), $\beta$-BHC (33\%), $\alpha$-chlordane (94\%), $\gamma$-chlordane (100\%), cis-nonachlor $(67 \%)$ and mirex $(22 \%)$. There were no cases where an organochlorine compound was not detected originally and then detected in the second paired sample. Organochlorine concentrations were not lipidadjusted because there should be little variation within an individual, especially since the sampling regimen incorporated into this study was designed to minimize variation in blood lipids. Indeed, the second lipid samples taken were on average within $15 \%$ of the original values and not significantly different from the first sample (paired t-test: $\mathrm{t}=-0.615, p=0.556$; Wilcoxon Sign-Rank test: $\mathrm{z}=-0.479$, $p=0.632$ ). For lead, only one sample had no detectable concentration; half the detection limit (i.e., $5 \mu \mathrm{g} / \mathrm{L}$ ) was used to replace this value to allow for statistical analyses. Paired t-tests (two-tailed) were performed with respect to each individual for total PCBs as Aroclor 1260, $\mathrm{DDDT}$, hexachlorobenzene, oxychlordane, trans-nonachlor, and lead. Data were also analyzed employing Wilcoxon SignRank tests (two-tailed).

\section{RESULTS}

Concentrations of contaminants in MCRL workers before and after working in the contaminated site are given in Table 1. Paired t-tests and Wilcoxon Sign-Rank tests showed a consistent result: no significant changes in the concentrations of contaminants measured in MCRL workers from the first to the second sample (Tables 2, 3).

\section{DISCUSSION}

The FN MCRL workers performed an important function preparing for Phase 2 of the delineation process by clearing trees and brush from critical areas of Site 050 . This work allowed for the completion of the delineation process, which resumed in September 1999 (ESG, 1999b). Further, the new fence built by these workers enclosed the contaminated area, thereby physically isolating the contaminated area from the community of Fort Albany (ESG, 1999b). The two new buildings built in the clean area were also important in allowing for the proper decontamination of workers before they left the site. Indeed, the precautionary measures taken to protect the health of the workers were sufficient for the tasks they performed, as it was shown that there was no significant increase in body burden of Aroclor 1260, $\mathrm{DDDT}$, hexachlorobenzene, oxychlordane, trans-nonachlor, or $\mathrm{Pb}$ in any of the participating workers (Tables 2,3). Air and dust were not monitored for contaminants at this stage of the delineation 
TABLE 2. Paired t-tests of concentrations of contaminants in MidCanada Radar Line workers prior to and after working in the contaminated site.

\begin{tabular}{|c|c|c|c|c|c|}
\hline \multirow[t]{2}{*}{ Test Pair } & \multirow{2}{*}{$\begin{array}{c}\text { Paired } \\
\text { Differences }\end{array}$} & \multicolumn{2}{|c|}{$\begin{array}{l}95 \% \mathrm{CI} \text { of } \\
\text { Difference }\end{array}$} & \multirow[t]{2}{*}{$\mathrm{t}$} & \multirow[t]{2}{*}{$p$} \\
\hline & & Lower & $\overline{\text { Upper }}$ & & \\
\hline Aroclor 1260 & $-0.027 \pm 0.315$ & -0.269 & 0.215 & -0.254 & 0.806 \\
\hline$\Sigma \mathrm{DDT}$ & $-0.016 \pm 0.133$ & -0.118 & 0.087 & -0.351 & 0.734 \\
\hline Hexachlorobenzene & $-0.001 \pm 0.014$ & -0.010 & 0.012 & 0.229 & 0.824 \\
\hline Oxychlordane & $-0.003 \pm 0.011$ & -0.012 & 0.005 & -0.894 & 0.397 \\
\hline Trans-nonachlor & $-0.004 \pm 0.015$ & -0.016 & 0.007 & -0.883 & 0.403 \\
\hline Lead & $-2.111 \pm 17.055$ & -15.220 & 10.988 & -0.371 & 0.720 \\
\hline
\end{tabular}

process, as it was felt that worker activity would create little dust. During actual remediation of Site 050, air and dust were constantly monitored on site and found to be within Canadian guidelines (G. Iannucci, pers. comm. 2004).

The methods we used to monitor FN MCRL workers preparing Site 050 for delineation, Phase 2, in JuneAugust 1999 were substantially different from those used by Health Canada for workers employed during the remediation of Site 050, which was completed in 2001. As stated in the Health Canada report (2001:2), "Following the completion of the remediation activities in September 2001, the Ontario Ministry of Natural Resources asked Health Canada to assist with the assessment of any health effects resulting from PCB exposure among Fort Albany First Nation community members who assisted with remediation of the contaminated soil." To meet this need, Health Canada (2001) collected serum samples on 29 and 30 September 2001, from 17 people (16 males and 1 female) who had participated in the remediation of Site 050. Serum samples were analyzed for total PCBs as Aroclor 1260 and eight congeners. A participant's detectable concentrations of PCBs were presented as whole blood values (serum values were divided by a factor of 2 ) and described as being within the normal range $(n=14$, minimum $=0.50 \mu \mathrm{g} / \mathrm{L}$, no maximum value was given, median $=0.73 \mu \mathrm{g} / \mathrm{L}$ ) when compared to Health Canada "Guidelines for PCBs in Humans" for whole blood (Health Canada, 2001).

A problem exists in Health Canada's blood collection protocol, in that PCB levels were assessed approximately one month after the workers had finished working in the contaminated site. This type of sampling would have missed any pulses of labile and unexpected PCB congeners because serum levels can decrease rapidly, to near ambient levels by 48 hours, depending on the route of exposure (Hansen, 1998). Furthermore, the workers' contaminant levels were not determined before they began to work in the contaminated area. The lack of a preexposure contaminant measurement makes it impossible to determine whether the person working in the contaminated zone experienced an increase in contaminant body burden while working on the site. The repeated measures
TABLE 3. Wilcoxon Sign-Rank tests of concentrations of contaminants in Mid-Canada Radar Line workers prior to and after working in the contaminated site.

\begin{tabular}{lcc}
\hline \hline Test Pair & $\mathrm{z}$ & $p$ \\
\hline Aroclor 1260 & -0.703 & 0.482 \\
EDDT & -0.415 & 0.678 \\
Hexachlorobenzene & -0.141 & 0.888 \\
Oxychlordane & -0.966 & 0.334 \\
Trans-nonachlor & -0.707 & 0.480 \\
Lead & -0.140 & 0.889 \\
\hline \hline
\end{tabular}

approach employed in the present study can detect any pulses of PCBs and on-site uptake of contaminants by workers so that an increase in PCB concentration can be ascertained. The approach we are advocating is based on the precautionary principle. That is, existing scientific data are insufficient to link negative health outcomes (other than dermal and liver function) conclusively to PCBs; nevertheless, it is logical to limit any work activity that increases exposure to and uptake of PCBs. If significant changes in contaminant levels had been found in the present study, we would have recommended modifications in the safety measures employed.

The Government of Alberta's Department of Labour established specific occupational health and safety guidelines for the monitoring of worker exposure and uptake of PCBs at the province's PCB treatment facility at Swan Hills, Alberta (Alberta Labour, 1994). These guidelines described remedial action for several blood-serum PCB levels (note: serum and plasma concentrations are comparable): lower than $10 \mu \mathrm{g} / \mathrm{L}$, no action required; $10-29 \mu \mathrm{g} / \mathrm{L}$, a review of potential sources of PCBs and annual blood retesting; $30-100 \mu \mathrm{g} / \mathrm{L}$, immediate blood retesting and, if initial level is confirmed, work task modification (to reduce exposure) and regular monitoring of PCB concentration and liver enzymes; and $100+\mu \mathrm{g} / \mathrm{L}$, removal of the worker from the PCB treatment facility and monthly monitoring of PCB levels (Alberta Labour, 1994). An important point not specifically addressed is that potential workers with serum PCB levels of $10 \mu \mathrm{g} / \mathrm{L}$ or more should not be considered for employment where there will be exposure to PCBs because their PCB levels are already of concern. All workers in the present study had PCB concentrations in plasma of $5.3 \mu \mathrm{g} / \mathrm{L}$ or lower at the start of their work term (Table 1). The importance of measuring PCB levels in personnel before they work on a contaminated site cannot be overemphasized because this protocol will identify people at risk who should not be working in conditions likely to increase their body burden of PCBs. This approach also allows for the tracking of PCB exposure over time, which may be important for identifying unsafe working conditions or protection methods or both.

Partnerships that include both economic and training opportunities are important to FNs (Schell and Tarbell, 1998). Nonetheless, FNs or other employers have a responsibility to ensure the health of their workers, 
especially during work on remediation projects. Other Aboriginal groups have entered or will be entering into agreements to collaborate with government organizations for the remediation of other MCRL sites in Ontario (Technical Working Group, 2001) and across Canada (Government of Canada, n.d.; Cree-Naskapi Commission, 2002; Kativik Regional Government, 2003). Aboriginal governing bodies must have safety measures in place that are adequate to protect their community members working in the contaminated sites. Such measures are especially important for sites such as MCRL Site 427, where geographical constraints will necessitate hand excavation of contaminated soil (ESG, 1999a). We strongly recommend pre-job and near-end-of-job contaminant monitoring, at the very least, as part of the worker safety protocol for future remediation projects.

\section{ACKNOWLEDGEMENTS}

We would like to thank Guy Iannucci, as well as Chief Mike Metatawabin and the Council of Fort Albany FN, and especially the workers who participated in the study. Ian Martin provided much appreciated statistical services.

\section{REFERENCES}

ALBERTA LABOUR. 1994. Occupational health and safety guideline: Guideline for medical monitoring of workers exposed to polychlorinated biphenyls (PCBs). Edmonton: Alberta Labour.

AMAP (ARCTIC MONITORING AND ASSESSMENT PROGRAMME). 1998. Assessment report: Arctic pollution issues. Oslo, Norway: Arctic Monitoring and Assessment Programme.

BRIGHT, D.A., DUSHENKO, W.T., GRUNDY, S.L., and REIMER, K.J. 1995a. Evidence for short-range transport of polychlorinated biphenyls in the Canadian Arctic using congener signatures of PCBs in soils. The Science of the Total Environment 160/161:251-263.

BRIGHT, D.A., GRUNDY, S.L., and REIMER, K.J. 1995b. Differential bioaccumulation of non-ortho-substituted and other PCB congeners in coastal Arctic invertebrates and fish. Environmental Science and Technology 29:2504-2512.

BRIGHT, D.A., DUSHENKO, W.T., GRUNDY, S.L., and REIMER, K.J. 1995c. Effects of local and distant contaminant sources: Polychlorinated biphenyls and other organochlorines in bottom-dwelling animals from an Arctic estuary. The Science of the Total Environment 160/161:265-283.

CREE-NASKAPI COMMISSION. 2002. Cree-Naskapi Commission 2002 report. Ottawa, Ontario: Cree-Naskapi Commission.

DOWNS, A.T. 1999. Comments on toxicologist report for Fort Albany MCL Site. Ottawa, Ontario: Department of National Defence.

DUSHENKO, W.T., GRUNDY, S.L., and REIMER, K.J. 1996. Vascular plants as sensitive indicators of lead and PCB transport from local sources in the Canadian Arctic. The Science of the Total Environment 188:29-38.

ESG (ENVIRONMENTAL SCIENCES GROUP). 1999a. MidCanada Line 1998 site assessment/delineation. Kingston, Ontario: Royal Military College, Environmental Sciences Group.

- 1999b. Fort Albany, Site (050). Site remediation phase one: Delineation 1999. Kingston, Ontario: Royal Military College, Environmental Sciences Group.

FERBER, D. 2002. Overhaul of CDC panel revives lead safety debate. Science 298:732.

FOSTER, W.G., and HOLLOWAY, A.C. 2003. Do environmental contaminants adversely affect human reproductive physiology? Journal of Obstetrics and Gynaecology Canada 24:33-44.

FRANK, R., BRAUN, H.E., and THORPE, B. 1993. Comparison of DDE and PCB residues in the general diet and in human blood: Ontario 1986-87. Bulletin of Environmental Contamination and Toxicology 51:146-152.

GERHARD, I., DANIEL, V., LINK, S., MONGA, B., and RUNNEBAUM, B. 1998. Chlorinated hydrocarbons in women with repeated miscarriages. Environmental Health Perspectives 106:675-681.

GIBSON, K.M. 1993. Abandoned radar sites Mid-Canada Radar Line Site investigation. August 9-11, 1993. Timmins, Ontario: Ministry of Environment and Energy.

GOVERNMENT OF CANADA. n.d. Activities and expenditures of federal departments and agencies, 1998-1999. www.aincinac.gc.ca/pr/agr/que/cin009_e.pdf. Accessed 13 April 2005.

HANSEN, L.G. 1998. Stepping backward to improve assessment of PCB congener toxicities. Environmental Health Perspectives 106:171-189.

HEALTH CANADA. 2001. Assessment of PCBs among 17 Fort Albany First Nation community members. Ottawa, Ontario: Health Canada, First Nations and Inuit Health Branch.

HILL, D.T. 1999. Mid-Canada Line Site 050 (Fort Albany) cleanup. Unpubl. report by D. Hill \& Associates. Available from Fort Albany First Nation, Band Office, Fort Albany, Ontario P0L 1H0.

HUEBERT, R.B. 2000. Security and the environment in the postCold War in the Arctic. Environment and Security 4:101-117.

HUNTER, L. 1998. Notice of meeting Mid-Canada Line environmental clean-up protocol. Available from Fort Albany First Nation, Band Office, Fort Albany, Ontario P0L 1H0.

JAMES, R.C., BUSCH, H., TAMBURRO, C.H., ROBERTS, S.M., SCHELL, J.D., and HARBISON, R.D. 1993. Polychlorinated biphenyl exposure and human disease. Journal of Occupational Medicine 35:136-148.

KATIVIK REGIONAL GOVERNMENT. 2003. Renewable resources department. www.krg.ca/en/departments/renewable/

KIMBROUGH, R.D. 1995. Polychlorinated biphenyls (PCBs) and human health: An update. Critical Reviews in Toxicology 25:133-163.

LAUWERYS, R.R., and HOET, P. 2001. Industrial chemical exposure guidelines for biological monitoring. 2nd ed. Florida: Lewis Publishers.

LEVIN, S.M., and GOLDBERG, M. 2000. Clinical evaluation and management of lead-exposed construction workers. American Journal of Industrial Medicine 37:23-43. 
MYERS, H., and MUNTON, D. 2000. Cold war, frozen wastes: Cleaning up the DEW Line. Environment and Security 4: $119-138$.

OMNR (ONTARIO MINISTRY OF NATURAL RESOURCES) 2000. Memorandum of understanding between the Ministry of Natural Resources and Fort Albany First Nation on the scope of the clean up of the Mid Canada Line site at Fort Albany. Peterborough, Ontario: Ministry of Natural Resources.

POLAND, J.S., MITCHELL, S., and RUTTER, A. 2001. Remediation of former military bases in the Canadian Arctic. Cold Regions Science and Technology 32:93-105.

ROGAN, W.J., and WARE, J.H. 2003. Exposure to lead in children: How low is low enough? New England Journal of Medicine 348:1515-1516.

ROTHMAN, N., CANTOR, K.P., BLAIR, A., BUSH, D., BROCK, J.W., HELZLSOUER, K., ZAHM, S.H., NEEDHAM, L.L., PEARSON, G.R., HOOVER, R.N., COMSTOCK, G.W., and STRICKLAND, P.T. 1997. A nested case-control study of nonHodgkin lymphoma and serum organochlorine residues. Lancet 350:240-244.

SAFE, S.H. 2000. Endocrine disruptors and human health-is there a problem? An update. Environmental Health Perspective 108:487-493.

SANDANGER, T.M., BRUSTAD, M., LUND, E., and BURKOW, I.C. 2003. Change in levels of persistent organic pollutants in human plasma after consumption of a traditional northern Norwegian fish dish - Molje (cod, cod liver, cod liver oil and hard roe). Journal of Environmental Monitoring 5:160-165.
SCHELL, L.M., and TARBELL, A.M. 1998. A partnership study of PCBs and the health of Mohawk youth: Lessons from our past and guidelines for our future. Environmental Health Perspectives 106:833-840.

SKERFVING, S., SVENSSON, B., ASPLUND, L., and HAGMAR, L. 1994. Exposure to mixtures and congeners of polychlorinated biphenyls. Clinical Chemistry 40:1409-1415.

TECHNICAL WORKING GROUP. 2001. Second draft. Recommendation section, abatement strategy, Mid-Canada Line Radar bases. Timmins, Ontario: Ministry of Natural Resources. Available from Fort Albany First Nation, Band Office, Fort Albany, Ontario P0L 1H0.

THORNE, D.H. 2003. The Mid Canada Line 1958-1965. www.lswilson.ca/mcl.htm. Accessed 14 April 2005.

TSUJI, L.J.S., KATAQUAPIT, J., KATAPATUK, B., and IANNUCCI, G. 2001. Remediation of Site 050 of the Mid-Canada Radar Line: Identifying potential sites of concern utilizing traditional environmental knowledge. Canadian Journal of Native Studies 21:149-160.

WALKOWIAK, J., WIENER, J., FASTABEND, A., HEINZOW, B., KRAMER, U., SCHMIDT, E., STEINGRUBER, H., WUNDRAM, S., and WINNEKE, G. 2001. Environmental exposure to polychlorinated biphenyls and quality of the home environment: Effects on psychodevelopment in early childhood. Lancet 358:1602-1607.

WEBER, J.P. 1996. Quality in environmental toxicology measurements. Therapeutic Drug Monitoring 18:477-483. 